\title{
The possible protective effect of Omega 3 fatty acids against Bisphenol A induced disruption of pituitary-testicular axis in albino rat. Biohemical, Histological and Immunohistochemical study
} Original

\author{
Ahmed Mostafa Mahmoud ${ }^{1}$,Eman K. Nor-Eldin' ${ }^{2}$ Hoda M. Elsayed ${ }^{2}$
}

Department of Physiology ${ }^{1}$, Department of Histology ${ }^{2}$, Faculty of Medicine, Sohag University

\begin{abstract}
Background: Infertility is a major health problem affecting human life. Multiple factors contribute to male infertility. The most important one is exposure to environmental contaminants (e.g. Bisphenol A (BPA)).

Aim of the work: To study the possible protective effect of Omega 3 against BPA induced changes in the pituitary testicular axis in rats.

Material and method: 30 adult male albino rats were used in the study. They were divided equally into 3 groups 10 animals each. Group I served as control. Group II received BPA in a dose $1.2 \mathrm{mg} / \mathrm{kg}$ orally 6 days a week. Group III received Omega 3 in a dose $0.4 \mathrm{~g} / \mathrm{kg}$ subcutaneously in addition to BPA of the same previous dose and duration. At the time of sacrifice, all rats were anesthetized with ether.Blood samples were collected for estimation of testosterone, LH, FSH and prolactin. The testes and pituitary were dissected out and processed for histological and immunohistochemical study for Caspase 3, PCNA and prolactin. The number of Caspase 3 and PCNA positive cells were counted and statistically analyzed.

Results: Marked decrease in serum LH, testosterone with marked increase in serum prolactin was observed in BPA treated group. Spermatogenic cells were disorganized and degenerated. Spermatids had fragmented pyknotic nuclei. A significant increase in the rate of apoptosis and a significant decrease in the rate of proliferation of germ cells were detected on BPA exposure compared to the control . Examination of pars distalis revealed degenerative changes in acidophils and basophils in group II animals with decreased intensity of reactive mammotrophs. These changes were ameliorated in group III by administration of Omega 3 fatty acids.
\end{abstract}

Conclusion: Omega 3 may protect against BPA hazardous effects through pituitary testicular axis pathway.

Received: 18 October 2018, Accepted: 15 December 2018

Key Words: Bisphenol A, infertility, LH, omega-3, pituitary testicular axis.

Corresponding Author: Hoda Mohammed Elsayed, M.D., Department of Histology, Faculty of Medicine, Sohag University, Egypt, Tel.: +20 1093882036, E-mail: hoda_abdelrasowl@med.sohag.edu.eg

ISSN: 1110-0559, Vol. 42, No. 1

\section{INTRODUCTION}

About $50 \%$ of couple's infertility is due to male factors ${ }^{[1]}$. Male factors roughly could be classified into genetic (chromosomal abnormalities) or non genetic ${ }^{[2]}$. Regarding non genetic factors, at least $10 \%$ are exogenous and reversible such as the impacts of lifestyle, environmental and psychological factors ${ }^{[3]}$.

A variety of chemical compounds have been released into the environment due to marked expansion of chemical industries worldwide. Male exposure to these chemical contaminants, which are estrogen mimics and endocrine disruptors, has been claimed as one of the causative factors contributing to the increasing male infertility ${ }^{[2]}$.

Bisphenol A (BPA) [2.2-bis (4hydroxylphenyl) propane] is one of the endocrine disrupting chemicals. It is used in the manufacture of many products as water pipes, baby bottles, lunch boxes and toys ${ }^{[4]}$. Humans may gain exposure to BPA through various routes like the air, absorption through the skin, fresh and marine surface waters and groundwater ${ }^{[5]}$.
Under the effect of the hypothalamic GnRH the hypothalamus controls androgen biosynthesis; this in turn stimulates LH and FSH release from the pituitary. LH in turn stimulates Leydig cell to secrete testosterone ${ }^{[6]}$.

Omega-3 polyunsaturated essential fatty acids are found in large amounts in fish oil. It contains eicosapentaenoic acid (EPA) and docosahexaenoic acid (DHA) ${ }^{[7]}$. Essential fatty acids are vital for many functions including growth, reproduction, vision, and brain development ${ }^{[8]}$. Additionally, could affect steroidogenesis and some transcription factors controlling gene expression ${ }^{[9]}$. Previous studies documented the antioxidant, anti apoptotic and anti inflammatory effects of omega- 3 fatty acids on various tissues exposed to stress and damage ${ }^{[10,11]}$.

Being a synthetic estrogen with the capability of binding to estrogen receptors in reproductive organs ${ }^{[5]}$, BPA could disrupt the normal mechanism. So our hypothesis in this study is that BPA may affect male fertility through disruption of pituitary testicular axis and that omega- 3 can protect against this harmful effect. 


\section{MATERIALS AND METHODS}

\section{Animals:}

This study was carried out in accordance with the guidelines of the University Animal Ethics and approved by Research Ethics Committee considering care and use of laboratory animals. 30 adult male albino rats about (200-250) gm weight were used for this study. They were obtained from Animal facility, Faculty of Medicine, Assuit University. All rats were kept under observation for two weeks prior to the experiments to permit the animals to adjust to the environments. The animals were housed in standard suitable cages $(20 \times 32 \times 20 \mathrm{~cm}$ for every 4 rats $)$ in controlled temperature room $\left(23^{\circ} \mathrm{C} \pm 1^{\circ} \mathrm{C}\right)$ with normal light and dark cycle. They were maintained on a standard diet of commercial rat chow and tap water.

\section{Experimental design:}

Animals were divided into 3 groups 10 animals each as follow:

Group I: Animals were served as the control group

Group II: Animals were received BPA dissolved in distilled water and given in a dose $1.2 \mathrm{mg} / \mathrm{kg}$ orally via gastric gavage 6 days a weak for 3 weeks. The dose chosen below a dose that is previously considered safe ${ }^{[12,13]}$.

Group III: Rats were received omega-3 in a dose (Fresenius Company, Germany) of $0.4 \mathrm{~g} / \mathrm{kg}$ subcutaneously in addition to BPA in the same previous dose and duration ${ }^{[14]}$.

\section{Materials:}

BPA (purity $>99 \%$ ) was purchased from Cornel Lap Company, Cairo, Egypt.

Omega-3 used in this study was in the form of fish oil-

3-Monoclonal antibodies for immunohistochemal study;

AntiPCNA, anti caspase 3 and antiprolactin antibodies. They were purchased from Medico company, Cairo, Egypt.

\section{Hormonal assay}

At the end of experimental period, blood samples were collected from the retro-orbital venous plexus by using heparinized capillary tubes (about $0.75-1.0 \mathrm{~mm}$ internal diameter) inserted in the medial canthus. The collected blood samples were kept in dry graduated plastic centrifuge tubes until coagulated. Blood samples were centrifuged at $4000 \mathrm{rpm}$ for about 10 minutes to separate the serum. The serum was sucked out into Eppendorf tubes and all specimens of sera were stored at $-20^{\circ} \mathrm{C}$ until used for the determination of:

- $\quad$ Testosterone $e^{[15]}$.

- $\quad$ LH, FSH and prolactin ${ }^{[16]}$.

These hormones were measured by an ELISA kit (R\&D Systems, Inc.,Minneapolis, MN, USA) according to the manufacturer's protocol.

\section{Histological and immunohistochemical study}

Animals were anaesthetized using ether inhalation then they were sacrificed. Testicular specimens were fixed in Bouin solution while pituitary specimens were fixed in $10 \%$ formalin and processed for histological and immunohistochemical examination as follow:

Haematoxyline and eosin for general histological examination

PCNA and Caspase 3 antibodies for assessment of proliferation and apoptosis of spermatogenic cells respectively.

Prolactin antibody for demonstration of mammotrophs.

Immunohistochemical staining procedure: Paraffinembedded tissue sections were prepared and mounted on coated glass slides. The sections were deparaffinized and rehydrated through descending grades of alcohol. Endogenous peroxidase activity was blocked with $0.6 \%$ hydrogen peroxide for $10 \mathrm{~min}$ using a peroxidase blocking reagent. Antigen retrieval was performed by boiling the slides in citrate buffer solution ( $\mathrm{pH} \mathrm{6.0)}$. The slides were microwaved at high medium for $10 \mathrm{~min}$. The sections were incubated with the following dilutions of primary antibodies; anti-caspase $3(1 / 200)$ and anti-PCNA (1/400) and for antiprolactin $(1 / 100)$ at $4^{\circ} \mathrm{C}$ overnight, washed, and incubated with biotinylated secondary antibodies; they were then incubated with the avidin- biotin complex. Finally, the sections were counterstained with hematoxylin, dehydrated, cleared, and mounted ${ }^{[17]}$. Negative control sections were prepared with omission of the primary antibody.

\section{Morphometric study}

Using Leica Qwin $500 \mathrm{C}$ microscope at the Histology Department, Faculty of Medicine, Sohag University, the number of PCNA and Caspase 3 positive cells were counted in 10 non overlapping high-power fields.

\section{Statistical analysis}

Statistical analysis was done using the computer software program SPSS for Windows version 16.0 (SPSS Inc., Chicago, IL., USA). Data were expressed as means \pm S.E. Statistical significance for data was determined using a one-way analysis of variance (ANOVA), followed by a post-hoc test to make multiple comparisons between the 3 groups. Also correlation coefficients were done. $P<0.05$ was considered statistically significant.

\section{RESULTS}

\section{Biochemical results:}

In BPA treated group (Group II), a significant decrease in both of testosterone and $\mathrm{LH}$ hormone levels was found $(P<0.05)$. While there was a significant increase in prolactin hormone levels compared to the control group. There is a non significant increase in FSH levels when compared to control animals $(P>0.05)$ (Table 1) and (Histograms 1,2) 
After Omega -3 administrations (Group III) there was a significant increase in the levels of testosterone and LH hormones $(P<0.05)$, in association with a significant decrease in prolactin level when compared to BPA treated group. Omega -3 returns levels of these hormones to normal as compared to control group $(P>0.05)$. There was a non significant increase in FSH levels when compared to control animals $(P<0.05)$ (Table 1) and (Histograms 1,2).

\section{Histological examination of the testis:}

Examination of the control group revealed that, the testicular parenchyma was formed of closely packed seminiferous tubules which are surrounded with basal lamina, myoid cells and fibroblasts. The tubules are lined with many layers of spermatogenic cells namely, spermatogonia, primary spermatocytes, spermatids and sperms. Seminiferous tubules were separated by a narrow interstitium containing Leydig cells, macrophages and blood capillaries. Sertoli cells with their large pale nuclei were observed between spermatogenic cells (Fig.1\&2).

BPA treated group (Group II) examination showed thickened capsule and irregular outline of the seminiferous tubules. The spermatogenic cells were disorganized and degenerated and exhibited basophilic cytoplasm with intercellular vacuoles. Apparent decrease in the number of sperms within the seminiferous tubules compared to the control group. Some tubules have dislocated germ cells within the lumen (Fig.3\&4). Spermatids have fragmented pyknotic nuclei (fig.5).

Homogenous acidophilic material with some vacuoles (transudate, interstitial edema) was observed in the interstitial space in addition to congestion of blood vessels was noticed (fig.5). Arterioles are seen under the capsule which were dilated and have thick wall (Fig. 4).

Examination of group (Group III) showed; marked improvement in testicular changes which induced by BPA was observed. Seminiferous tubules had regular basement membrane with healthy looked spermatogenic lineages, some intercellular vacuoles were still observed. Some nuclei of primary spermatocytes showed chromatinolysis. No germ cells were seen dislocated within the tubules. Some interstitial fluid exudate was still present with no vascular congestion (Figs. 6\&7).

\section{Immunohistochemistry for PCNA:}

Seminiferous tubules of control animals had PCNA positive brown coloration in the nuclei of spermatogenic cells mainly spermatogonia (Fig. 8).

Seminiferous tubules of group II showed PCNA positive reaction in the nuclei of spermatogonia and primary spermatocytes nuclei and apparently decreased in number compared to control one (Fig. 9).While group III showed apparent increased in number of PCNA positive cells compared to BPA treated group (Fig. 10).

\section{Immunohistochemistry for caspase 3:}

Examination of the control group showed few apoptotic cells (fig.11), while Group II animals showed positivity in spermatogonia, primary spermatocytes and round spermatids (Fig. 12).

Examination of Group III animals, showed apparent decreased in number of positive cells compared to the previous treated group (Fig. 13).

\section{Morphometric study and statistical analysis}

Morphometric study and statistical analysis revealed a significant decrease in the number of PCNA positive germ in BPA treated group compared to the control group. It was noticed also a significant increase in the number of positive germ cells in group III compared to the previous group (table 2 and histogram 3).

Regarding Caspase 3 results there was a significant increase in the number of positive germ in BPA treated group compared to the control group. Whereas a significant decrease in the number of positive germ cells in group III compared to the previous group was observed (table 3 and histogram4).

\section{Histological examination of pars distalis:}

Pars distalis of adult control animal had chromophobes and chromophils. The latter consisted of two types, acidophils and basophils. Acidophils had rounded vesicular central nucleus and acidophilic cytoplasm. Basophils had rounded vesicular eccentric nuclei and basophilic cytoplasm. Chromophobes were seen as multiple small cells with rounded central nuclei and unstained cytoplasm. Multiple sinusoidal capillaries were noticed in between cells of pars distalis (Fig. 14).

Examination of Group II animals, Pars distalis had acidophils which have dense rounded nuclei and acidophilic cytoplasm. Numerous basophils had vesicular nuclei and marked vacuolated cytoplasm (Fig. 15).

Examination of Group III animals, Pars distalis have some acidophils with acidophilic cytoplasm and rounded vesicular nuclei,others still had dense nuclei. Basophils had vacuolated cytoplasm and vesicular nuclei. Some basophils still had dense nuclei (Fig. 16).

\section{Immunohistochemistry of mammotrophs:}

Pars distalis of adult control animals had cells positive for prolactin antibody (mammotrophes). They have brown coloration of their cytoplasm (Fig. 17).

Examination of Group II animals showed apparent increase in intensity of reaction in the cytoplasm of mammotrophs compared to the control group (Fig. 18).

Examination of Group III animals showed apparent decreased in intensity of brown coloration of mammotrophs compared to the previous group (Fig.19). 


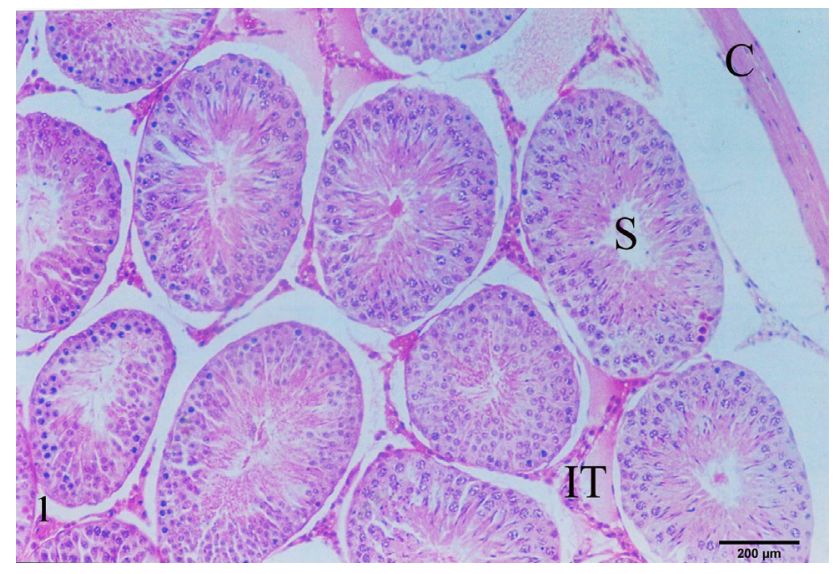

Fig .1: A photomicrograph of control animal testis showing; seminiferous tubules (S) are surrounded by basement membrane and lined with germ cells. In between the tubules there are interstitial areas (IT) and the capsule can be seen (c).

(H\&E x 200)

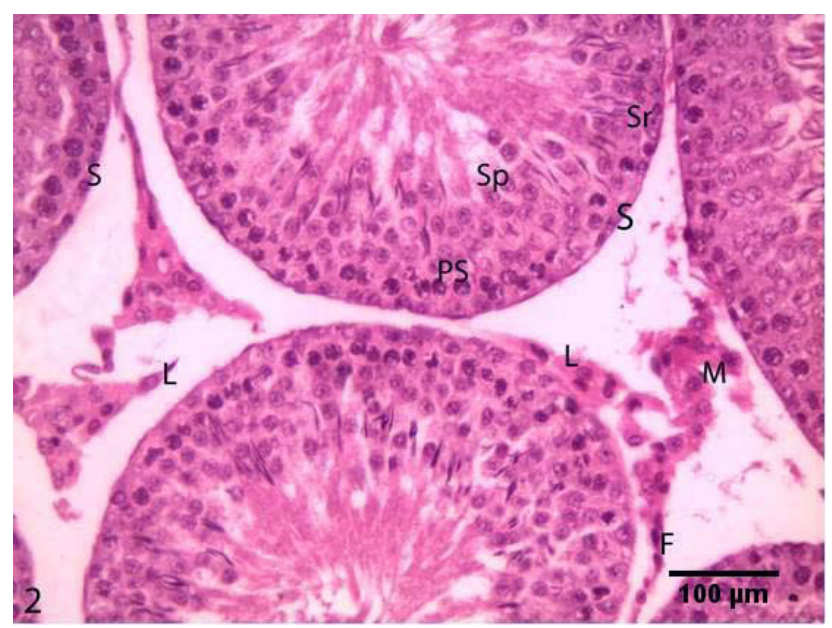

Fig. 2: A magnified part of previous section showing; parts of five seminefrous tubules. They are surrounded by intact regular basement membrane, nuclei of myoid cells and fibroblasts. Note: Germ cells lined the tubule are spermatogonia (s), primary spermatocyte (ps), spermatid (Sp) and sertoli cell (Sr) Interstitial area has leydig cell (L), fibroblast (F) and macrophage(M). (Hx\&E x400)

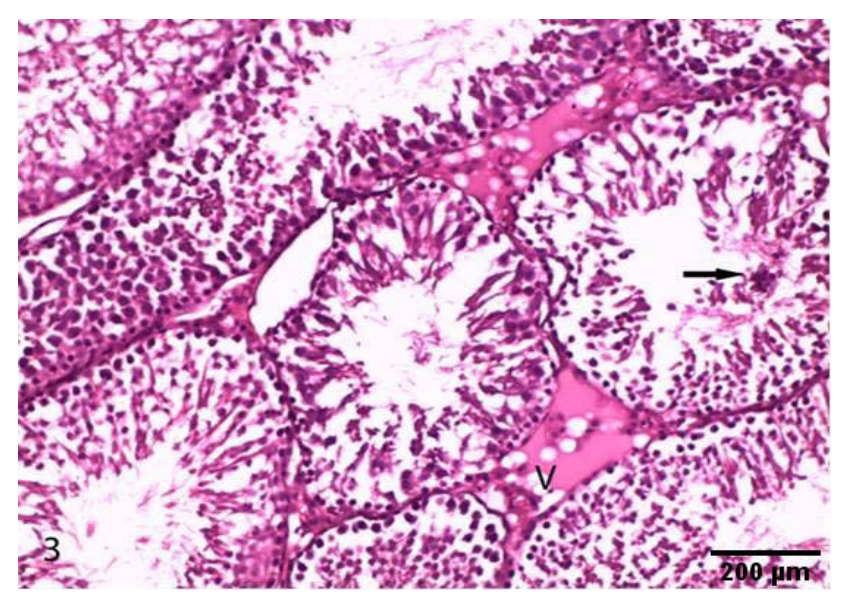

Fig. 3: A photomicrograph of testis treated with BPA showing: seminiferous tubules having irregular basement membrane (arrow head) and desquamated germ cells with wide spaces in between. Interstitial area show acidophilic material in between cells with multiple vacuoles (v) Note: desquamated cells inside the tubule $(\uparrow)$.

(Hx X200)

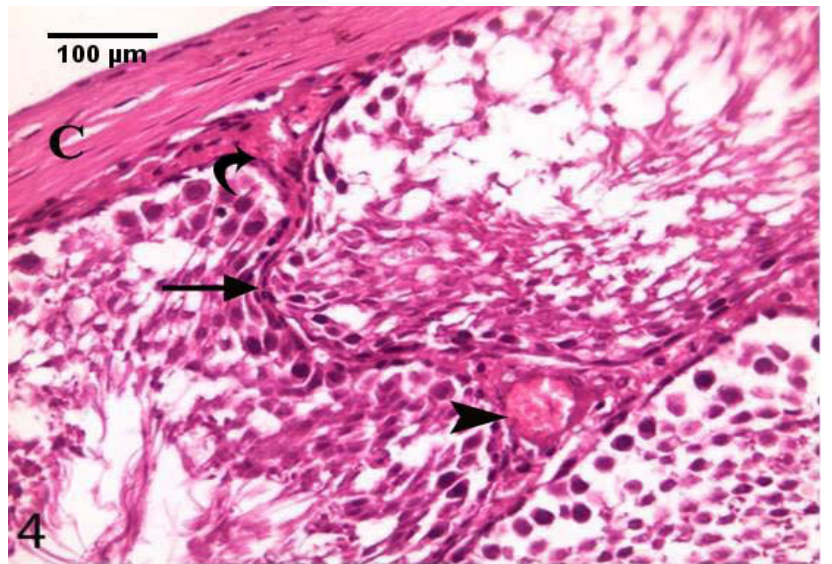

Fig. 4: A photomicrograph of testis treated with PBA showing; thick testicular capsule(c), seminiferous tubules have irregular outline (arrow) and congested dilated blood vessel (arrow head) and thick walled arteriole (curved arrow).

(H \&E x400)

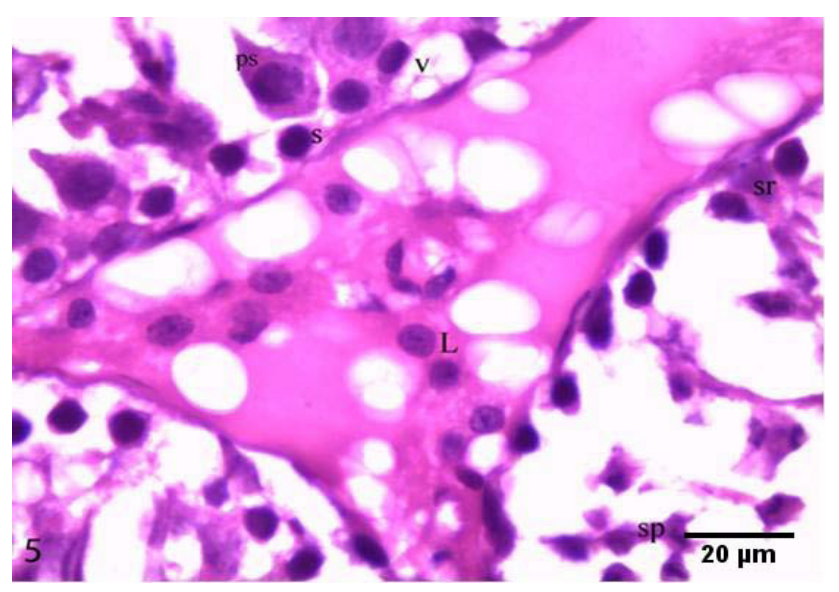

Fig. 5: A photomicrograph of testis of treated animal showing; three parts of seminiferous tubules have irregular basement membrane, spermatogonia (s) have dark condensed nuclei, primary spermatocytes (ps) with dense nuclei and basophilic cytoplasm, spermatids (sp) have fragmented and pyknotic nuclei.Sertoli cells (sr) have dense nuclei. Wide spaces and multiple vacuoles (v) in between germ cells. Note: Acidophilic vacuolated exudate is seen in interstitium with normal Leydig cells (L).

$(\mathrm{H} \& \mathrm{E} \quad \mathrm{x} 1000)$

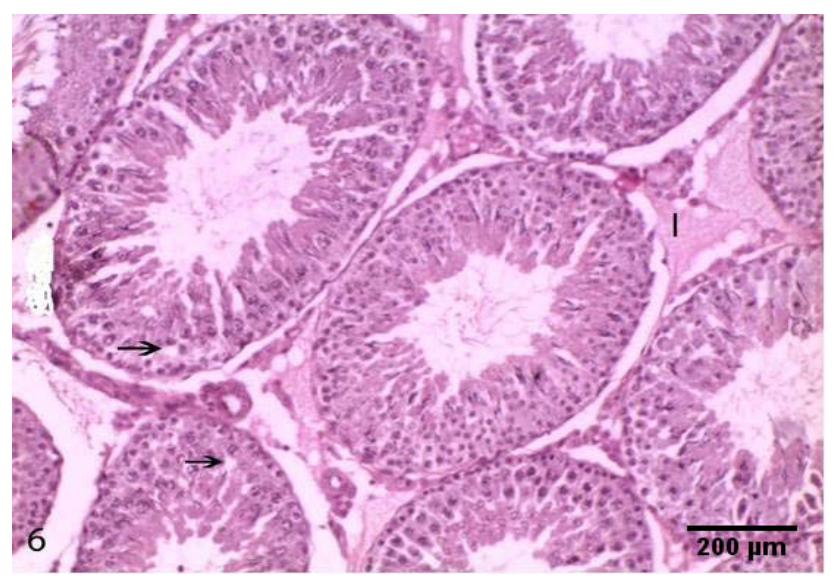

Fig. 6: A photomicrograph of testis treated with BPA and omega3showing: seminiferous tubules having almost regular basement membrane and germinal epithelium with few vacuoles in between $(\uparrow)$. Note: some exudate is still seen in interstium (I).

(H\&Ex200) 


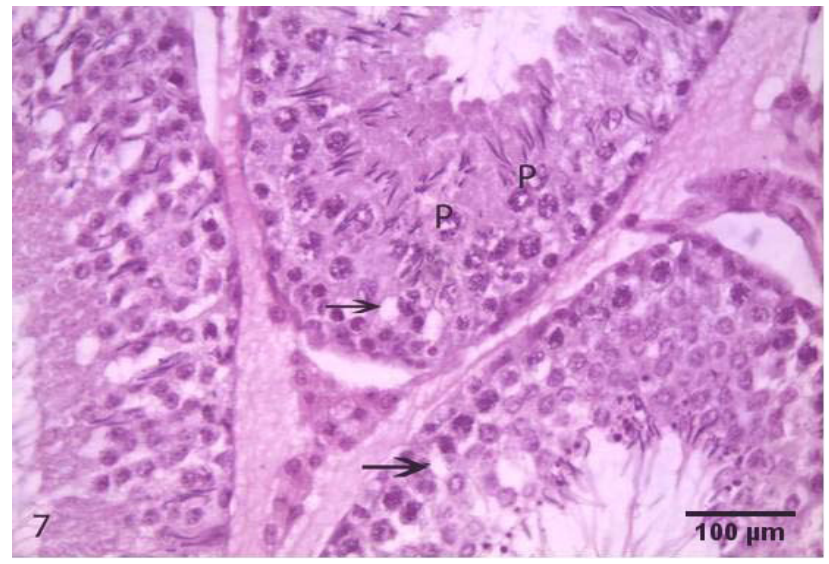

Fig. 7: A photomicrograph of testis treated with BPA and omega 3showing: seminiferous tubules have regular basement membrane and spermatogenic cell. Some nuclei of primary spermatocytes show chromatinolysis (P).In between germ cells few vacuoles are seen $(\uparrow)$

$(\mathrm{H} \& \mathrm{E} \times 400)$

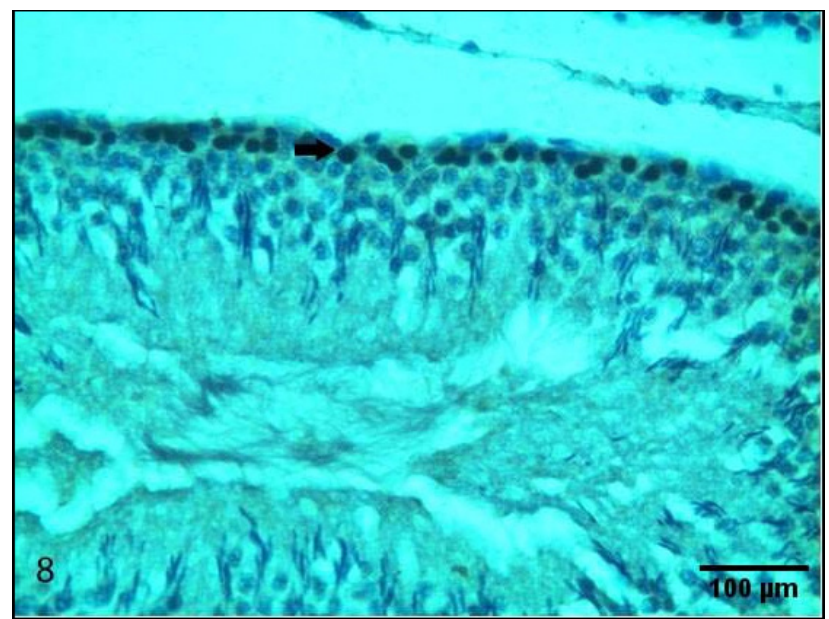

Fig. 8: A photomicrograph of control testis immunostained for PCNA showing; PCNA positive nuclei of spermatogonia (arrow head). Weak positive intensity is seen in cytoplasm of primary spermatocytes (arrow).

(PCNA immunostain $x 400)$

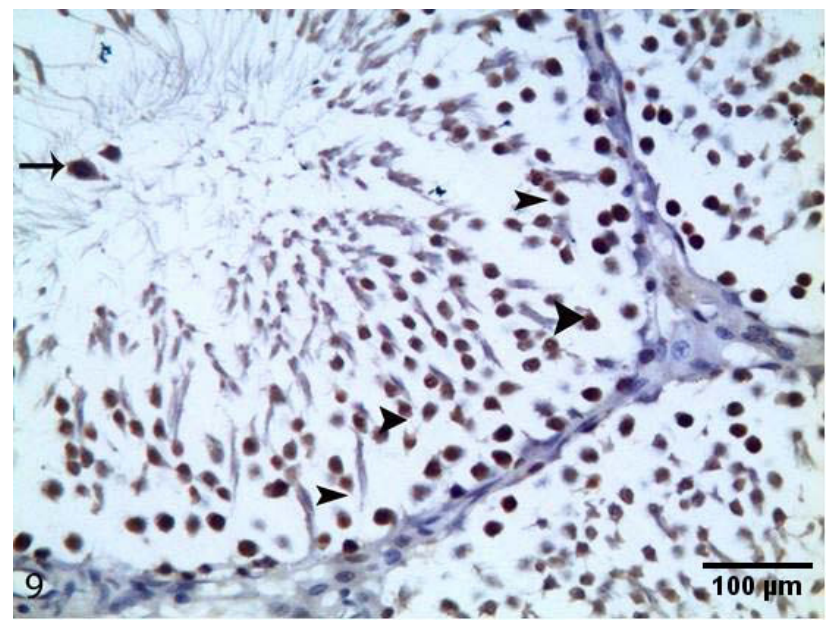

Fig. 9: A photomicrograph of GII testis immunostained for PCNA showing; PCNA positive nuclei of spermatogonia and primary spermatocytes (arrow head). Note: desquamated cells have positive nuclei for PCNA immunostain (arrow).

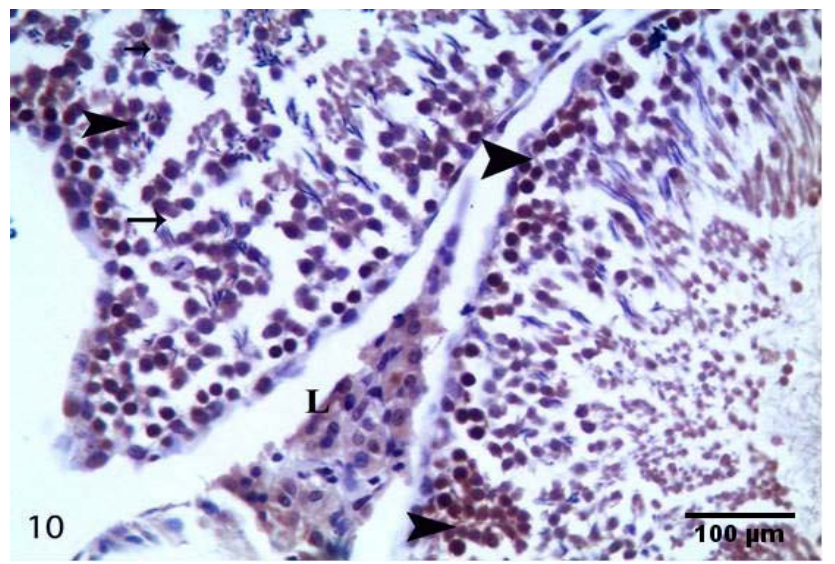

Fig. 10: A photomicrograph of GIII testis immunostained for PCNA showing; increase number of PCNA positive cells, nuclei of spermatogonia (arrow head) and primary spermatocytes (arrow). cytoplasmic positivity of Leydig cells (L)

(PCNAimmunostain $\mathrm{x} 400$ )

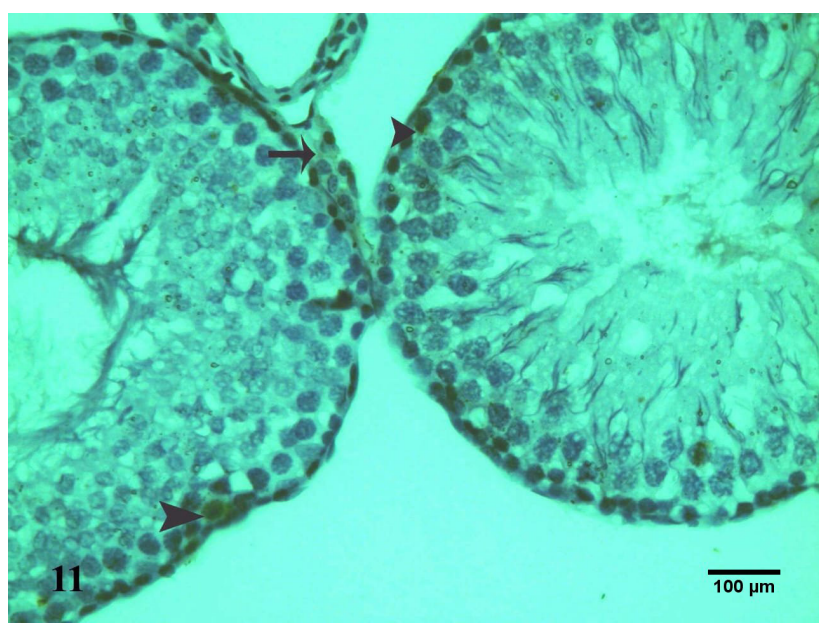

Fig.11: A photomicrograph of the testis of control group immunostained for caspase 3 showing; two adjacent seminiferous tubules with few caspase 3 positive spermatogonia (arrow head). Note, Leydig cell (arrow). (caspase 3 immunostain $\mathrm{x} 400$ )

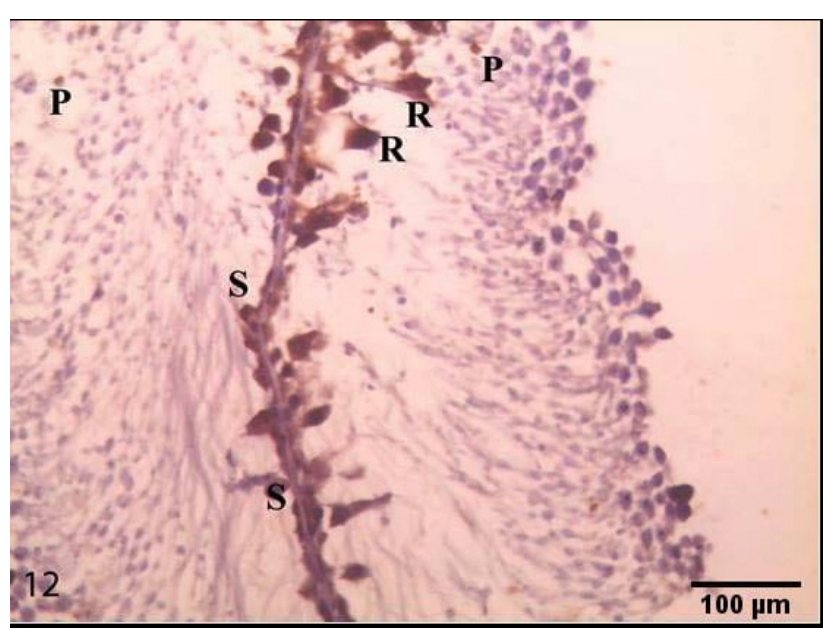

Fig. 12: A photomicrograph of GII testis immunostained for caspase 3 showing; two adjacent seminiferous tubules. Positive reaction appeared in spermatogonia $(S)$, primary spermatocytes $(R)$ and round spermatids $(p)$.

(caspase 3 immunostain $\mathrm{x} 400$ ) 


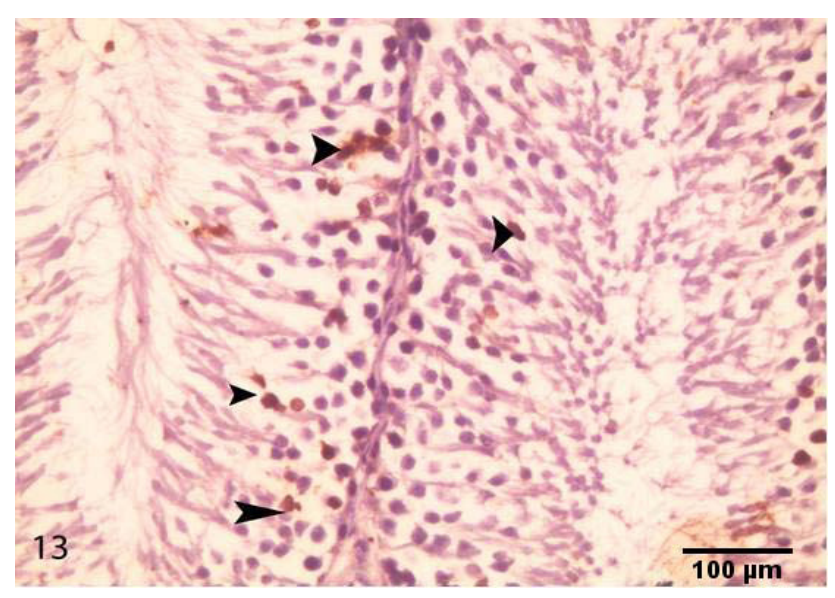

Fig. 13: A photomicrograph of GIII testis immunostained for caspase 3 showing; two adjacent seminiferous tubules have apparently decreased number of positive cells compared to the previous group (Arrow head).

(immunostain caspase $3 \times 400)$.

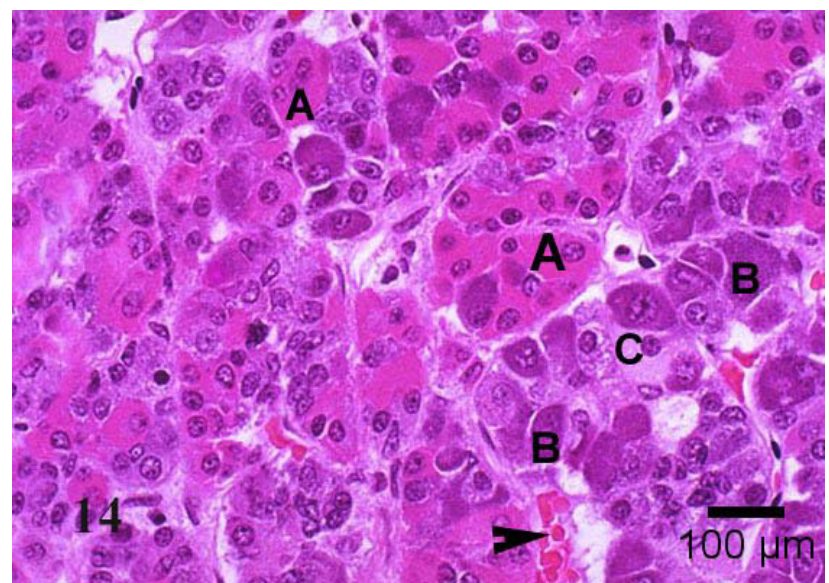

Fig. 14: A photomicrograph of adult control pituitary gland showing; Part of pars distalis have acidophils with rounded vesicular central nucleus and acidophilic cytoplasm (A). Basophils (B) have rounded vesicular eccentric nuclei and basophilic cytoplasm. Multiple small cells with rounded central nuclei and unstained cytoplasm called chromophobes (C). Note: Sinusoidal capillaries are seen between cells (arrow head) (H\&EX400)

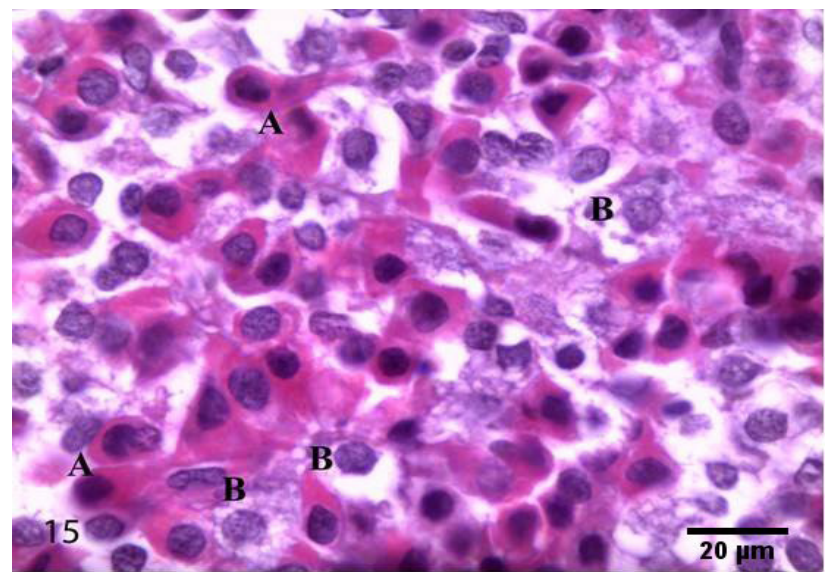

Fig. 15: A photomicrograph of GII pituitary gland showing; Part of pars distalis. Acidophils have dense rounded nuclei and acidophilic cytoplasm (A). Basophils have vesicular nuclei and marked vacuolated cytoplasm (B).

(H\&E x400)

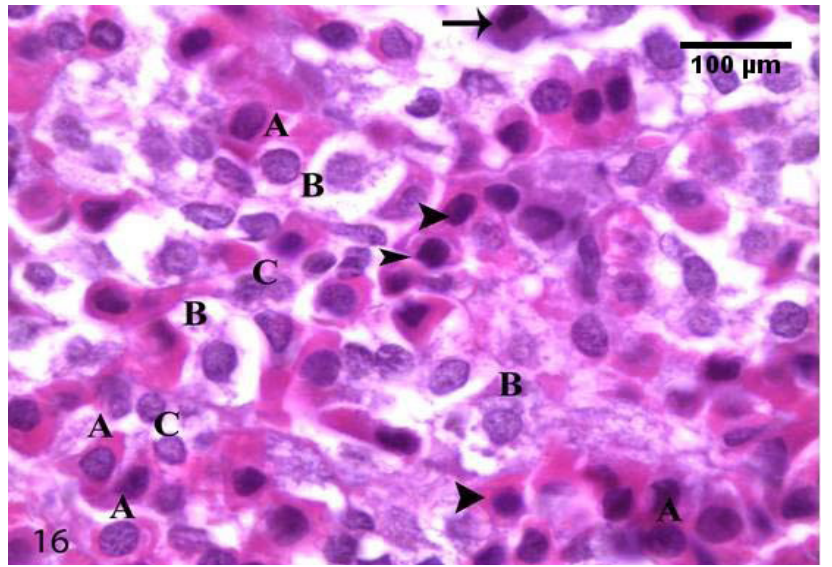

Fig. 16: A photomicrograph of GIII pituitary gland showing; Part of pars distalis. Acidophils (A) have acidophilic cytoplasm and rounded vesicular nuclei. Some acidophils have dense nuclei (arrow head).Basophils (B) have vacuolated cytoplasm and vesicular nuclei. Some basophils have dense nuclei (arrow).

(H \&E X1000)

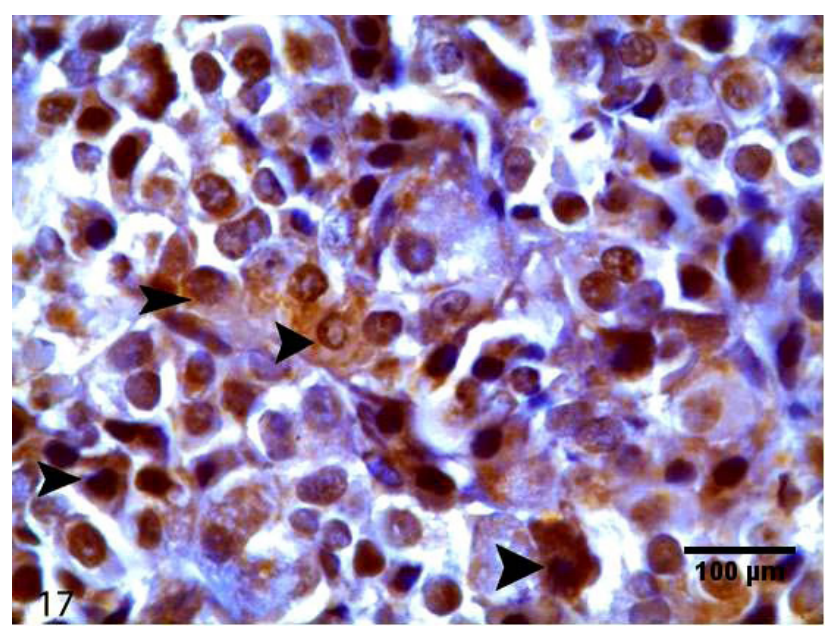

Fig. 17: A photomicrograph of adult control pituitary gland showing; Part of pars distalis have cells positive for prolactin antibodies (arrow head). They have brown coloration of cytoplasm.

(immunostain for prolactin $\mathrm{x}$ 1000)

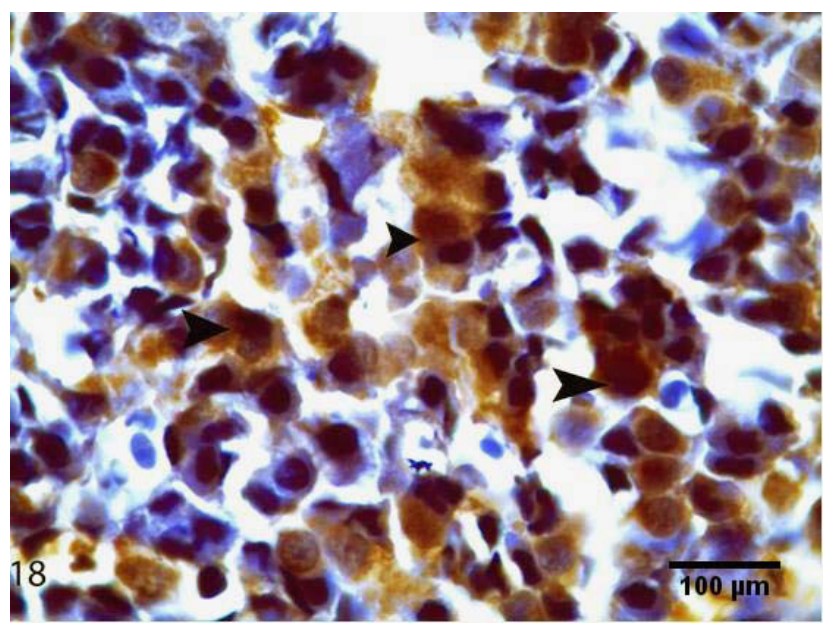

Fig. 18: A photomicrograph of G II pituitary gland (Part of pars distalis) showing; apparent increased intensity of reaction in the cytoplasm of mammotrophs compared to controls (arrow head).

(immunostain for prolactin $\mathrm{x} 1000$ ) 


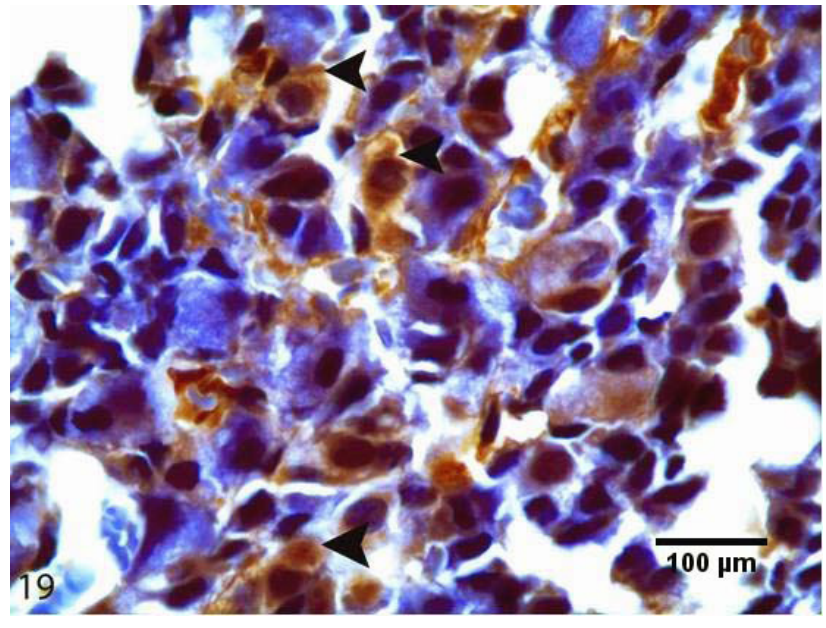

Fig. 19: A photomicrograph of G III pituitary gland showing; Part of pars distalis, Mammotrophs showing apparent decreased intensity of brown coloration compared to previous group (arrow head).

(immunostained for prolactin x 1000)

Table 1: showing the differences in the mean levels of hormones between the three studied groups

\begin{tabular}{ccccc}
\hline Groups & $\begin{array}{c}\text { Control } \\
\text { (Group I) }\end{array}$ & $\begin{array}{c}\text { BPA treated } \\
\text { (Group II) }\end{array}$ & $\begin{array}{c}\text { Treated with } \\
\text { BPA + omega3 } \\
\text { (Group III) }\end{array}$ & P-value \\
\hline $\begin{array}{c}\text { Testosterone } \\
(\mathrm{ng} / \mathrm{ml})\end{array}$ & $16.47 \pm 0.42$ & $10.45 \pm 0.68^{\#}$ & $14.94 \pm 0.80^{*}$ & 0.0001 \\
$\mathrm{LH}(\mathrm{U} / \mathrm{ml})$ & $11.80 \pm 0.85$ & $7.07 \pm 0.51^{\#}$ & $10.45 \pm 1.24^{*}$ & 0.003 \\
$\begin{array}{c}\text { FSH }(\mathrm{U} / \mathrm{ml}) \\
\text { Prolactine } \\
(\mathrm{ng} / \mathrm{ml})\end{array}$ & $2.41 \pm 0.57$ & $3.56 \pm 0.40$ & $2.50 \pm 0.51$ & 0.21 \\
\hline
\end{tabular}

Data represent the mean $\pm \mathrm{SD}$. of observations from 10 male rats

* Significant compared to bisphenol group $<0.05$ )

\# Significant compared to control group $(P<0.05)$.

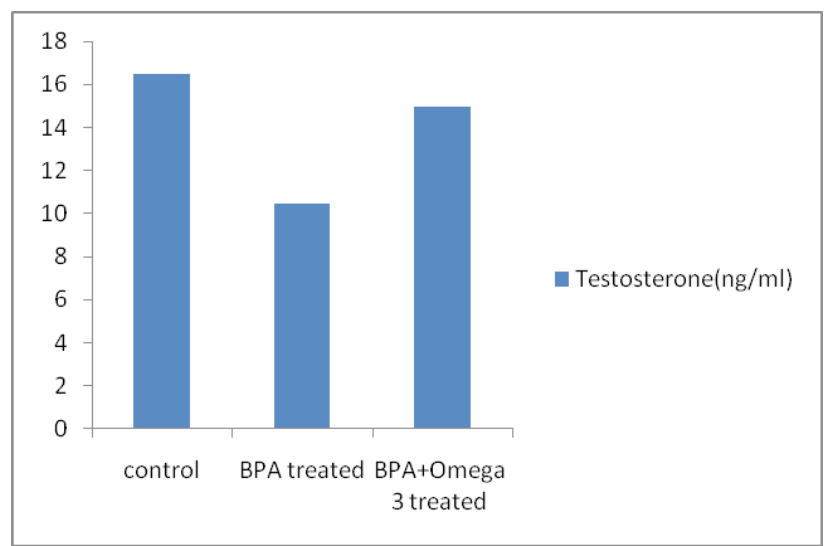

Histogram 1: Showing the differences in the mean level of testosterone .in the three studied groups

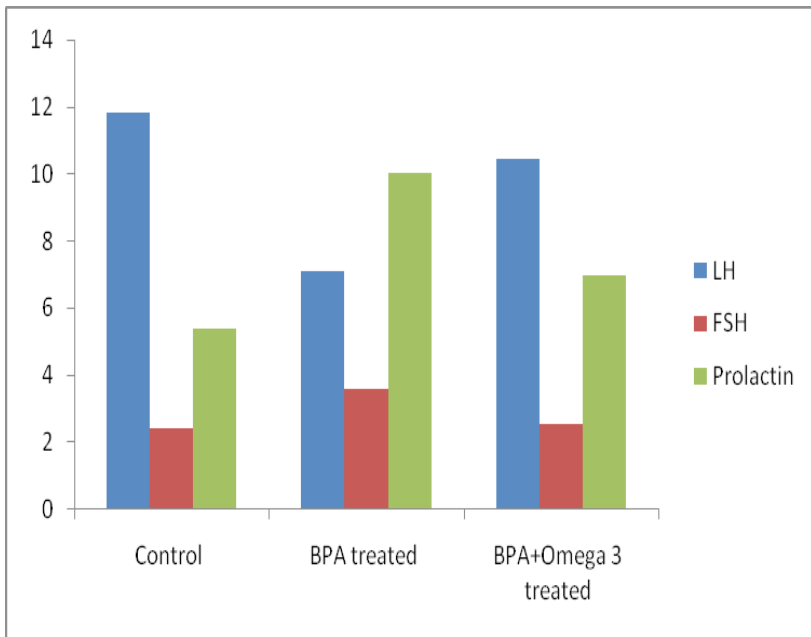

Histogram 2: Comparison of the three studied groups regarding the mean levels of LH, FSH and prolactin.

Table 2: Comparison of the three studied groups regarding the mean number of PCNA positive cells.

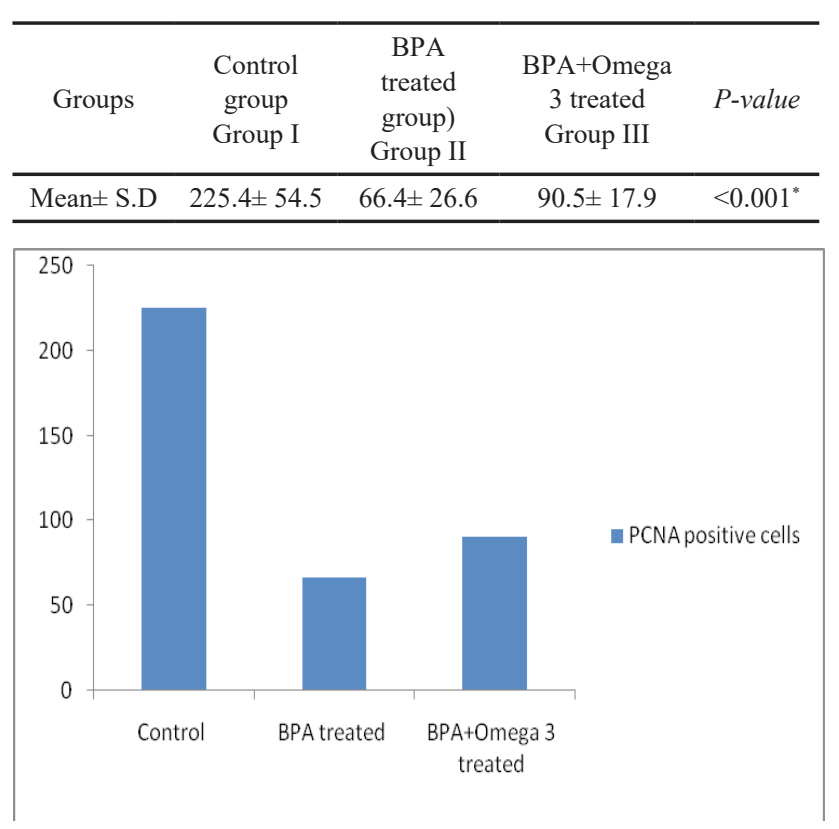

Histogram 3: Comparison of the three studied groups regarding the mean number of PCNA positive cells.

Table 3: Comparison of the three studied groups regarding the mean number of Caspase 3 positive cells.

\begin{tabular}{ccccc}
\hline \multirow{2}{*}{ Groups } & Control & BPA & BPA+Omega & \\
& group & $\begin{array}{c}\text { treated } \\
\text { group) } \\
\text { Group I }\end{array}$ & $\begin{array}{c}3 \text { treated } \\
\text { Group III }\end{array}$ & $P$-value \\
& & Group II & & \\
\hline Mean \pm S.D & $1.1 \pm 0.3$ & $3.6 \pm 2.1$ & $1.5 \pm 0.6$ & $<0.001^{*}$ \\
\hline
\end{tabular}




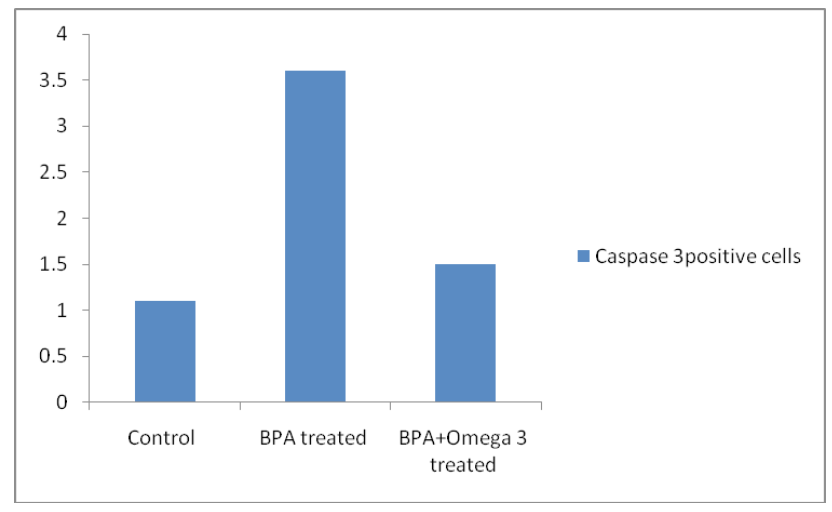

Histogram 4: Comparison of the three studied groups regarding the mean number of Caspase 3 positive cells

\section{DISCUSSION}

BPA is an endocrine-disrupting chemical that can induce a variety of adverse effects in mammals ${ }^{[18]}$. Worldwide, about 50-80 million individuals are infertile, an estimate that is likely to increase considerably in the future. Several factors are known to underlie male infertility. Exposure to environmental toxicants as BPA could be one of these factors ${ }^{[19]}$. Human body can be exposed to BPA through food containers, water bottles, thermal papers and medical equipments as dental fillings ${ }^{[20]}$. The testis is vulnerable to damage by environmental toxicants as $\mathrm{BPA}^{[19]}$.

Our results revealed that there was an irregular outline of the seminiferous tubules with degeneration and disorganization of spermatogenic cells with intercellular vacuolation. It is reported that a decrease in the level testosterone in BPA-treated rats led to atrophy of seminiferous tubules, degeneration of cells, and complete absence of spermatogenesis ${ }^{[21]}$. Also, the impairment of the basal lamina of seminiferous tubules and damaged tight junctions between sertoli cells could be attributed to BPA-induced cell injury as reported by ${ }^{[22]}$. Additionally, the intercellular spaces represent progressive degenerative changes affecting cell membrane integrity secondary to oxidative stress induced by BPA. The free radicals oxygen species initiate oxidative phosphorylation reactions to cell membranes ending in disruption of the integrity of the intercellular junctional complexes ${ }^{[23]}$.

An apparent decrease in the number of sperms within the lumen of some tubules was observed compared to the control. A significant increase in the rate of apoptosis and a significant decrease in the rate of proliferation of germ cells were also detected on BPA exposure compared to the control group.

Our results were in agreement with the study of Jin and his collegues ${ }^{[2]}$ who have been reported that, the number of spermatocytes, spermatogonia, and spermatids and the concentration of testosterone may be reduced in male rats on exposure to BPA at $2 \mathrm{ug} / \mathrm{kg}$. These results suggest that BPA could inhibit spermatogenesis ${ }^{[25]}$. Furthermore, any decrease in the level of testosterone may decrease the number of sperms. While Qiu and his collogue reported that BPA dose $(5 \mathrm{mg} / \mathrm{kg})$ in male rats showed a significant decline in the number of sperms ${ }^{[26]}$.

Similar results were previously reported as well by $^{[27]}$. While Takahashi and Oishi found the delay of spermatogenesis and the disorganization of elongated spermatids of male rats when exposed to BPA only at higher levels ${ }^{[28,29]}$.

BPA may act via several different mechanisms involving interaction with estrogen receptors and/or by production of a minor but potent estrogenic metabolite ${ }^{[30]}$. A decrease in the level of androgen binding protein could be the possible mechanism for the reproductive toxicity of $\mathrm{BPA}^{[22]}$. Others reported that a low BPA concentration can induce spermatogenesis disorders mainly through decreasing androgen receptor expression ${ }^{[26]}$. Hatef et al. consider that BPA may exert both anti-androgenic and estrogenic effects, depending on concentration, to impair sperm production ${ }^{[31]}$. However Previous study reported that, BPA could up-regulate mRNA expression of $E R \alpha^{[32]}$.

A number of studies point out that the adult exposure BPA can reduce sperm production and efficiency of spermatogenesis ${ }^{[33,34]}$. Liu et al found that exposure of pregnant mice to BPA during pregnancy and lactation has some toxic effects on the testes of male offspring and these may originate from increased apoptosis ${ }^{[35]}$.

Pengpeng and his collogues ${ }^{[36]}$ explained germ cell apoptosis through decreasing reproductive hormones and activating the Fas/FasL signaling pathway. The Fas-signaling system is considered to be a key regulator of germ cell apoptosis during development and after testicular insults ${ }^{[37,38]}$.

Furthermore BPA exposure increased the protein and mRNA levels of cytochrome $\mathrm{C}$, apoptosis-inducing factor, caspase-3/9, and Bax; caspase- 3 and caspase- 9 activities; and the apoptosis indices of spermatogenic cells. In addition, abnormal structure of mitochondria and decreased protein and gene levels of Bcl-2 were observed following BPA exposure ${ }^{[39]}$.

The caspase family is a class of cysteine proteases. Active caspases play a crucial role in the transduction of apoptotic signals ${ }^{[38]}$. Relevant caspases include the initiator caspases (caspases-8, -9, and -10) and the effector caspases (caspases-3, -6, and -7). Germ cell apoptosis can be a result of a reduced intratesticular testosterone concentration and the translocation of active caspase- 3 and caspase-activated deoxyribonuclease to the nucleus which led to the induction of apoptosis ${ }^{[40]}$.

Wang and his colleague reported that mitochondrial pathway mediated apoptosis was observed in rat testis due to BPA exposure led to reproductive system dysfunction ${ }^{[39]}$.

A previous in vitro study has revealed the cytotoxicity of low dose BPA through the up-regulation of Bax and the down-regulation of Bcl-2[41]. Additionally, BPA-induced apoptotic cell death through calcium-mediated oxidative stress $^{[42]}$. 
Our data in the present study revealed a statistically significant decrease in the level of LH and testosterone in BPA treated group in comparison to control group. These results come in agreement with ${ }^{[43,44,45,46]}$. They reported that BPA has adverse effects on testicular function by decreasing pituitary LH secretion and reducing Leydig cells steroid genesis "primary gonadal failure"[47].

BPA suppressed testosterone production via a decreased LH secretion. There is also evidence that BPA interferes with LH receptor-legend binding ${ }^{[5]}$. The decreased serum testosterone level could be primarily postulated to the decreased expression of the steroidogenic enzymes and cholesterol carrier protein "StAR" involving the testosterone synthesis as decreased $\mathrm{LH}^{[48,49,50]}$. Furthermore BPA is reported to act as anti-androgenic agent blocking the action of dihydrotestosterone ${ }^{[51]}$.

Our study showed disagreement with results obtained by others in rats ${ }^{[52]}$ and in mice ${ }^{[53]}$. They found that there was non-significant change in testosterone level following BPA exposure when compared with control. This variation may be due to differences in animal species, dose of BPA and time of exposure. The decreased LH level as obtained in our study could be explained by ability of BPA to interfere with $\mathrm{LH}$ receptor ligand binding resulting in uncoupling LH from LH receptor that potentially contributes to diminished LH stimulation of steroid genesis as reported by $^{[54]}$ or due to increased prolactin release after BPA exposure as mentioned by ${ }^{[55]}$, where hyperprolactinemia has been shown to cause reproductive dysfunction as confirmed by ${ }^{[56]}$. This dysfunction is not mediated via direct action on testis but due to its effects at the level of hypothalamus-pituitary to inhibit LH-RH and LH secretion as confirmed by ${ }^{[5]}$.

In contrast to the significant increase in LH levels, FSH levels showed no significant changes by BPA administration. Since FSH secretion is mainly regulated by inhibin, it could be not affected by BPA ${ }^{[57]}$. The hormonal changes were associated with degenerative changes in basophils.

Our data in the present study revealed that administration of BPA increased prolactin secretion in addition to increased mammotroph immunoreactivity. These results similar to those were observed by ${ }^{[5,59,60]}$.

The effect of BPA is probably due to direct action to anterior pituitary via calcium influx in pituitary cells ${ }^{[61]}$. BPA may simulate estrogen to increase the level of serum prolactin, because estrogen has a direct role in stimulating prolactin gene expression. BPA could have hypothalamic actions and can alter levels of progesterone receptor expression within the medio-basal hypothalamus. This induced neural system changes that could have impact upon gonadotrophin secretion ${ }^{[5]}$.

Administration of omega 3 in the present study ameliorates both the hormonal changes as well as the morphological changes in both testis and pars distalis.
Omega-3 (n-3) is an essential fatty acid found in large amounts in fish oil. It contains eicosapentaenoicacid (EPA) and docosahexaenoic acid (DHA) $)^{[7]}$.

We found a statistically significant increase in serum LH, Testosterone level associated with a significant decrease in serum prolactin in omega 3 treated group compared to BPA treated group. These results agree with others ${ }^{[62,63,64,65,66]}$

Omega 3 increases nitric oxide release as reported by ${ }^{[67,68]}$ and by previous work by ${ }^{[69]}$. Nitric oxide increases the release of GnRH, which in its turn increases gonadotropin secretion in the pituitary gland ${ }^{[70]}$. Nitric oxide activates Guanylate cyclase enzyme that causes the release of cyclic guanosine monophosphate and eventually by raising GnRH, LH and FSH, enhances sperm motility and induces erection in males ${ }^{[64]}$. Also omega 3 is able to inhibit 5 alpha - reductase in cell cultures and cellfree systems. There by preventing the conversion of testosterone to dihydrotestosterone. In this way omega 3 prevent the reduction of plasma testosterone level ${ }^{[71]}$. However, it appears that the increase in testosterone levels with omega-3 was due to its direct effect on Leydig cells.Omega-3 contains alpha linolenic acid, which can be converted to arachidonic acid, as a precursor to make type 2 prostaglandins like E2 ${ }^{[72]}$. Arachidonic acid seems to play an important role in testicular steroid genesis. As researches indicated that, arachidonic acid increases cyclic adenylate cyclase, thus enhancing the rate of cholesterol side-chain breakage and stimulating the production of testosterone. So, these compounds mediate the testosterone production via messaging. Previous Studies on showed that all E series prostaglandins stimulated testosterone production in the testes ${ }^{[64]}$. In the present study, the rate of germ proliferation was significantly increased and the rate of apoptosis was significantly decreased by administration of Omega-3. Previous studies documented the antioxidant, anti apoptotic and anti inflammatory effects of fish n-3 fatty acids on various tissues exposed to stress and damage ${ }^{[10,11]}$, so it can be a promising potential cytoprotective agent against various extrinsic toxic stimuli.

Uygur and his college found that omega-3 decreased germ cell apoptosis and oxidative stress induced by doxorubicin $^{[72]}$. Additionally, omega-3 could protect against experimental diabetes-induced damages on testis, sperm parameters and preimplantation embryo development in rat model ${ }^{[73]}$.

Also, cell membrane fluidity can be improved by increasing dietary omega-3 and changes in fatty acid contents of cell membrane reported to be achieved rapidly within weeks by altering dietary fat intake ${ }^{[74]}$.

\section{CONCLUSION}

BPA induced disturbance in the pituitary testicular axis in rats in low dose which is previously considered to be safe and the concomitant use of omega 3 fatty acids could protect against BPA induced changes. 


\section{REFERENCES}

1. Campagne D. Can male fertility be improved prior to assisted reproduction through the control of uncommonly considered factors? Int J Fertil Steril.2013; 6(4): 214-223.

2. Sharma A,: Male infertility; Evidences, Risk Factors, Causes, Diagnosis and Management in Human. Ann Clin Lab Res. 2017; Vol. 5:No.3:188.

3. Ramlau-Hansen C., Thulstrup A., Aggerholm A., Jensen M., Toft G. and Bonde J.: Is smoking a risk factor for decreased semen quality? A cross-sectional analysis. Hum Reprod.2007; 22(1): 188-196.

4. Susan C. and John J.: Bisphenol A: A Model Endocrine Disrupting Chemical with a New Potential Mechanism of Action. Endocrinology.2013; 154(6): 1962-1964.

5. Eman G., Mohamed A. and Neama M.: Effect of Bisphenol A on the First Generation of Female Rats from Both Parents Treated with the Same Xenoestrogen. The Egyptian Journal of Hospital Medicine.2016; Vol. 64, Page 389- 394.

6. Ramaswamy S. and Gerhard F.: Endocrine control of spermatogenesis: Role of FSH and LH/ testosterone. Spermatogenesis.2014; 4(2): 996025.

7. Sarsilmaz M, Songur A, Ozyurt H, Kus I, Ozen OA, Ozyurt B,Sogut S, Akyol O Potential role of dietary omega-3 essential fatty acids on some oxidant/antioxidant parameters in rats' corpus striatum. Prostaglandins Leuko Essent Fatty Acids. 2003; 69:253-259.

8. Gur MI,Harwood,JL, FraynKN. Lipid Biochemistry: An Introduction.5th ed.Oxford, U: Blackwell Science Ltd.; 2002

9. Wathes DC, Abayasekara DR, Aitken RJ. Polyunsaturated fatty acids in male and female reproduction. Biol Reprod. 2007; Aug; 77(2):190-201. 18.

10. Ozen OA, Cosar M, Sahin O, Fidan H, Eser O, Mollaoglu H, Alkoc O, Yaman M, Songur A: The protective effect of fish n-3 fatty acids on cerebral ischemia in rat prefrontal cortex. Neurol Sci. 2008;29: 147-152.

11. Zararsiz I, Kus I, Akpolat N, Songur A, Ogeturk M, Sarsilmaz M. Protective effects of omega-3 essential fatty acids against formaldehyde-induced neuronal damage in prefrontal cortex of rats. Cell Biochem Funct .2006 a; 24:237-244.

12. Moon MK, Kim MJ, Jung IK, Koo YD, Ann HY, Lee KJ, Kim SH, Yoon YC, Cho BJ, Park KS, Jang HC, Park YJ:( Bisphenol A impairs mitochondrial function in the liver at doses below the no observed adverse effect level. J Korean Med Sci. 2012 Jun; 27(6):644-52.
13. Wisniewski P, Romano PM, Kizys MM, Oliveira KC, Kasamatsu T,Giannocco G, Chiamolera MI, Dias-da-Silva MR, and Romano MA.: adult exposure to bisphenol A(BPA) reduces sperm quality with disruption off the hypothalamopituitary testicular axis. Toxicology.2015;2, 329, 1-6

14. Atakisi O, Atakisi E, Ozcan A, et al. Protective effect of omega-3 fatty acids on diethylnitrosamine toxicity in rats. Eur Rev Med Pharmacol Sci.2013;17(4):467-71.

15. Vanessa A., Aine M., Lauren Harte-H., Alejandra Magagna-P., Thomas R., Goutam C., Charles E., Neil J. and Scharfman H: Testosterone depletion in adult male rats increases mossy fiber transmission, LTP, and sprouting in area CA3 of hippocampus. $\mathrm{J}$ Neurosci. 2013 6; 33(6): 2338-2355.

16. Tietz N.W. (1995): Clinical Guide to Laboratory Tests. 3rd ed. Philadephia, WB. Saunders Co., 509-12.

17. Hekmat O. Abdel Aziz, Hoda M. Elsayed, Mohammed Ashraf A. Ali:Effect of mobile phone radiation on proliferation and apoptosis in rabbit testes: a histological and immunohistochemical study. Egyptian journal of histology; 2015, 38(3):670-678.

18. Oehlmann J, Oetken M, Schulte-Oehlmann U.A. critical evaluation of the environmental risk assessment for plasticizers in the freshwater environment in Europe, with special emphasis on bisphenol A and endocrine disruption. Environ Res 2008; 108:140-149.

19. Mruk DD, Cheng CY.: Environmental contaminants: is male reproductive health at risk? Spermatogenesis 2011; 1:283-290.

20. Acconcia F., Valentina P. and Maria M.: Molecular Mechanisms of Action of BPA: Dose-Response 2015:1-9.

21. Norazit A, Mohamad J, Razak SA, Abdulla MA, Azmil A, Mohd MA. Effects of soya bean extract, bisphenol A and 17 $\beta$-estradiol on the testis and circulating levels of testosterone and estradiol among peripubertal juvenile male SpragueDawley rats. Sains Malaysiana 2012; 41:63-69.

22. Tian J, Ding Y, She R, Ma L, Du F, Xia K, Chen L: Histologic study of testis injury after bisphenol A exposure in mice. Toxicol Ind Health.;2017 33(1):36-45.

23. El Ghazzawy IE, Meleis AE, Farghaly EF, Soaiman A. Histological study of the possible protective effect of pomegranate juice on bisphenol-A induced changes of the caput epididymal epithelium and sperms of adult albino rats. Alex J Med 2011; 47:125-137.

24. Jin $\mathrm{P}$, Wang $\mathrm{X}$, Chang F, Bai Y, Li Y, Zhou R, et al.: Low dose bisphenol A impairs spermatogenesis 
by suppressing reproductive hormone production and promoting germ cell apoptosis in adult rats. $\mathrm{J}$ Biomed Res. 2013 ;27:135-44.

25. El-Bassouny, Dalia R.; Hindawy, Mohamed: The adverse effects of bisphenol ' $A$ ' on some reproductive organs of the male albino rat: a light and electron microscopic study. Egyptian Journal of Histology: September 2013 - Volume 36 - Issue 3 - p 564-578

26. Qiu LL, Wang X, Zhang XH, Zhang Z, Gu J, Liu $\mathrm{L}$, et al. Decreased androgen receptor expression may contribute to spermatogenesis failure in rats exposed to low concentration of bisphenol A. Toxicol Letters. 2013; 219:116-24.

27. Sohrab Kazemi, Farideh Feizi, Fahimaeh Aghapour,Gholam Ali Joorsaraee, and Ali Akbar Moghadamnia: Histopathology and Histomorphometric Investigation of Bisphenol A and Nonylphenol on the Male Rat Reproductive System. N Am J Med Sci. 2016 May; 8(5): 215-221.

28. Takahashi $\mathrm{O}$ and Oishi S.Testicular toxicity of dietarily or parenterally administered bisphenol $\mathrm{A}$ in rats and mice. Food Chem.Toxicol.2003, vol.41 pg.1035-1044

29. TakahashiO, Oishi S:Testicular toxicity of dietary2,bis(hydroxyphenyl)propane (bisphenol A) in F344 rats,Arch.Toxicol.,2001, vol.75(pg.42-51).

30. Witorsch RJ. Low-dose in utero effects of xenoestrogens in mice and their relevance to humans: an analytical review of the literature. Food ChemToxicol. 2002; 40: 905-912

31. Hatef A, Zare A, Alavi SM, Habibi HR, Linhart O. Modulations in androgen and estrogen mediating genes and testicular response in male goldfish exposed to bisphenol A. Environ Toxicol Chem. 2012;31:2069-77.

32. Chao HH, Zhang XF, Chen B, Pan B, Zhang LJ,Li L, Sun XF,Shi QH and Shen W. Bisphenol A exposure modifies methylation of imprinted genes in mouse oocytes via the estrogen receptor signaling pathway

33. Chitra KC, Latchoumycandane C, Mathur PP. Induction of oxidative stress by bisphenol $\mathrm{A}$ in the epididymal sperm of rats. Toxicology. 2003;185:119-27.

34. Sakaue M, Ohsako S, Ishimura R, Kurosawa S, Kurohmaru M, Hayashi Y, et al. Bisphenol-A affects spermatogenesis in the adult rat even at low dose. J Occup Health. 2001;43:185-90.

35. Liu XL, Chen XY, Wang ZC, Shen T, Zhao H. Effects of exposure to bisphenol Aduring pregnancy and lactation on the testicular morphology and caspase-3 protein expression of ICR pups. Biomed Rep. 2013 May;1(3):420-424.
36. Pengpeng Jin,XiaoliWang, FeiChang, YinyangBai, YingchunLi, RongZhou, and Ling Chen. Low dose bisphenol A impairs spermatogenesis by suppressing reproductive hormone production and promoting germ cell apoptosis in adult rats.J Biomed Res. 2013 Mar; 27(2): 135-144.

37. Koji T, Hishikawa Y. Germ cell apoptosis and its molecular trigger in mouse testes. Arch HistolCytol. 2003;66:1-16.

38. Li YJ, Song TB, Cai YY, Zhou JS, Song X, Zhao X, Wu XL. Bisphenol A exposure induces apoptosis and upregulation of Fas/FasL and caspase-3 expression in the testes of mice.Toxicol Sci. 2009 Apr;108(2):427-36.

39. Wang P, Luo C, Li Q, Chen S, Hu Y. Mitochondrionmediated apoptosis is involved in reproductive damage caused by BPA in male rats. Environ Toxicol Pharmacol. 2014 Nov; 38(3):1025-33.

40. Kim JM, Ghosh SR, Weil AC, Zirkin BR: Caspase-3 and caspase-activated deoxyribonuclease are associated with testicular germ cell apoptosis resulting from reduced intratesticular testosterone. Endocrinology. 2001 Sep;142(9):3809-16.

41. Xu J, Osuga Y, Yano T, Morita Y, Tang X, Fujiwara $\mathrm{T}$, et al. Bisphenol A induces apoptosis and G2to-M arrest of ovarian granulosa cells. Biochem Biophys Res Commun. 2002; 292:456-62.

42. Lee S, Suk K, Kim IK, Jang IS, Park JW, Johnson VJ, et al. Signaling pathways of bisphenol A-induced apoptosis in hippocampal neuronal cells: role of calcium-induced reactive oxygen species, mitogen-activated protein kinases, and nuclear factor-kappaB. J Neurosci Res. 2008;86:2932-42.

43. Tohei A, Suda S, Taya K, Hashimoto T, Kogo H. Bisphenol A inhibits testicular functions and increases luteinizing hormone secretion in adult male rats.ExpBiolMed (Maywood) 2001; 226:216-21.

44. Akingbemi, B., Sottas, C., Koulova, A., Klinefelter, G. and Hardy, M. (2004): Inhibition of testicular steroidogenesis by the xenoestrogen bisphenol A is associated with reduced pituitary luteinizing hormone secretion and decreased steroidogenic enzyme gene expression in rat Leydig cells. Endocrinology 145, 592-603.

45. Mendiola J., Jørgensen N., Andersson A., Calafat A., Ye X., Redmon J., Drobnis E., Wang C., Sparks A., Thurston S., Liu F. and Swan S.: Are environmental levels of bisphenol a associated with reproductive function in fertile men? Environ Health Perspect.2010; 118(9):1286-91.

46. Justine M., Sarah J., Shane R. and Valerie S.: Plasticizer endocrine disruption: Highlighting developmental and reproductive effects in 
mammals and non-mammalian aquatic species, General and Comparative Endocrinology2015; 219 74-88.

47. Wan H., Dolores D., Chris K. and Yan C. (2013): Targeting testis- specific proteins to inhibit spermatogenesis; lesson from endocrine disrupting chemicals. Expert Opin Ther Targets; 17(7): 839-855.

48. Nakamura D.; Xanagika Y.; Duan, Z.; Ito Y.; Okamura, A.; Asaeda N.; Jagawa Y.; Naito, H.; and Nakajima; T. : Bisphenol A may cause testosterone reduction by adversely affecting both testis and pituitary systems similar to estradiol. Toxicology Letters.2010; 194, 16-25.

49. Chen H., Guo J., Ge R., Lian Q., Papadopoulos V. and Barry R.: Steroidogenic Fate of the Leydig Cells that Repopulate the Testes of Young and Aged Brown Norway Rats after Elimination of the Preexisting Leydig Cells. Exp Gerontol; 2015; 72: 8-15.

50. Robert L. and David A.: The Pathogenesis of Polycystic Ovary Syndrome (PCOS): The Hypothesis of PCOS as Functional Ovarian Hyperandrogenism Revisited. Endocr Rev. 2016 October; 37(5): 467-520.

51. Luccio-Camelo D. and Prins G.: Disruption of Androgen Receptor Signaling in Males by Environmental Chemicals. J Steroid Biochem Mol Biol; 2011;127(1-2): 74-82.

52. Kato, Y.; Furuhashi, T.; Tanaka, M.; Katsu,Y.; Watanabe, H.; Ohta, Y. and Iguchi, T.: Effects of bisphenol A given neonatally on reproductive function of male rats. Reproductive Toxicology.2006; 22: 20-29.

53. Kawai, K.; Nozaki, T.; Nishikata, H.; Aou, S.; Takii, M. and Kubo, C. :Aggressive betaviour and serum testosterone concentration during the maturation process of male mice. The effects of fetal exposure to bisphenol A. Environmental Health Perspectives.2003; 111, 2, 175-178.

54. Svechnikov K, Izzo G, Landreh J. and Soder O. (2010): Endocrine Disruptors and Leydig Cell Function. Journal of Biomedicine and Biotechnology; Article ID 684504, 10 pages.

55. Hao L., Zhang J., Zhang Y., Hu H., Shao W., Zhang X., Geng C., Wang Y. and Jiang L.(2016): Effect of bisphenol a on occurrence and progression of prolactinoma and its underlying mechanisms. Am J Transl Res; 8(10):4195-4204.

56. Majumdar A. and Sharma N.: Hyperprolactinemia. J Hum Reprod Sci.2013; 6(3): 168-175.

57. Kishi H., Itoh M, Wada S, Yukinari Y, Tanaka Y, Nagamine N, Jin W, Watanabe G. and Taya K.: Inhibin is an important factor in the regulation of FSH secretion in the adult male hamster. Am J Physiol Endocrinol Metab.2000; 278(4):E744-51.
58. Velasco-Marinero E, Herrero-Payo JJ and Carretero-Gonzalez J. (2011): Changes in pituitary and prolactin cells of Wistar rats after two dental fillings with bisphenolic resins. Arch Oral Biol ; 56: 592-598.

59. Brannick K., Craig Z., Himes A., Peretz J., Wang W, Flaws J. and Raetzman L.: Prenatal exposure to low doses of bisphenol A increases pituitary proliferation and gonadotroph number in female mice offspring at birth. Biol Reprod.2012; 87: 82.

60. Hassan A., Khudir A. and Ismael A.: Reproductive efficacy in female rat exposed to bisphenol A during gestation period. Bas J Res.2013; 12(2): 149-16.

61. Phelan N., O'Connor A., Kyaw T., Correia N., Boran G. and Roche H.: Hormonal and metabolic effects of polyunsaturated fatty acids in young women with polycystic ovary syndrome: results from a cross sectional analysis and a randomized, placebo-controlled, crossover trial. Am J Clin Nutr.2011; 93(3):652-62.

62. Yan L., Bai X., Fang Z., Che L., Xu S. and Wu D: Effect of different dietary omega-3/omega-6 fatty acid ratios on reproduction in male rats. Lipids in Health and Disease.2013 .12:33

63. Bostani M., Aqababa H., Ebrahim S. and Changizi S. : A Study on the Effects of Walnut oil on Plasma Levels of Testosterone Pre and Post Puberty in Male Rats. American Journal of Ethno medicine.2014; Vol. 1, No. 4, 266-275

64. Esmaeili V, Shahverdi A., Alizadeh A., Alipour H and Chehrazi M.: Saturated, omega-6 and omega-3 dietary fatty acid effects on the characteristics of fresh, frozen-thawed semen and blood parameters in rams. Andrologia. 2014 ; 46:42-9.

65. Nadjarzadeh A., Dehghani-Firouzabadi R., Daneshbodi H., Mohammad H.,Vaziri N. and Mozaffari-Khosravi H.(2015): Effect of Omega-3 Supplementation on Visfatin, Adiponectin, and Anthropometric Indices in Women with Polycystic Ovarian Syndrome. J Reprod Infertil ; 16(4):212-220.

66. Aleksandra Ż., Katarzyna M., Magda M. Zbigniew G. and Stanisław P.: Omega-3 fatty acids supplementation improves endothelial function and maximal oxygen uptake in endurance-trained athletes. European Journal of Sport Science.2015; 15 (4): 1-10.

67. Ross M., Malone E. and Florida-James G.: Vascular Ageing and Exercise: Focus on Cellular Reparative Processes. Oxidative Medicine and Cellular Longevity.2016, 1-15

68. Ahmed M. M.: Effect of Omega 3 and regular exercise on the muscle performance: Special prevalence of histamine and nitric oxide production. Al- Azhar Med.j.2017; Vol, 46(3): 739- 747.

69. Barnes MJ, Lapanowski K, Rafols JA, Lawson 
DM, Dunbar JC. Chronic nitric oxide deficiency is associated with altered leutinizing hormone and follicle-stimulating hormone release in ovariectomized rats. Exp Biol Med. 2002; 227(9):817-22

70. Park W., Son E., Nam G., Kim S., Noh M., Lee B. et al.: Torilin from Torilis japonica, as a new inhibitor of testosterone 5 alpha-reductase. Planta Med.2003; 69(5): 459-61.

71. Kobayashi M., Hori T. and Kawakami E.: Changes in prostaglandin E2 levels in seminal plasma during ejaculation and the effect of exogenous prostaglandin E2 on semen volume in the dog. J Vet Med Sci.2013; 75(9):1249-52.

72. R.Uygur, C.Aktas, F. Tulubas, E Uygur, M Kanter,
M Erboga, V Caglar and O.A.Ozen(): protective effect of fish omega 3 fatty acids on doxorubicin induced testicular apoptosis and oxidative damage. Androlgia. 2014; 46:917-926

73. Khavarimehr $M$, Nejati V, Razi M, Najafi G.: Ameliorative effect of omega-3 on spermatogenesis, testicular antioxidant status and preimplantation embryo development in streptozotocin-induced diabetes in rats. Int Urol Nephrol. 2017; 49(9):1545-1560.

74. de Lorgeril M., Salen P. Dietary prevention of coronary heart disease: focus on omega-6/omega-3 essential fatty acid balance., World Rev. Nutr. Diet. 2003; 92: 57-73. 


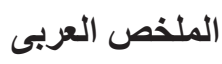

التأثير الوقائي المحتمل للأحماض الدهنية أوميغا ب ضد اضطراب

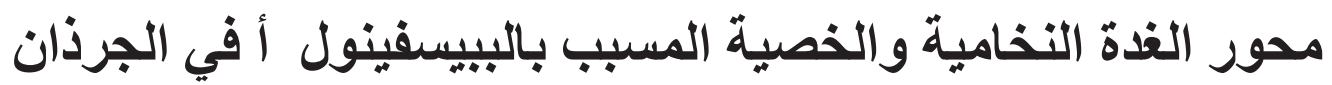

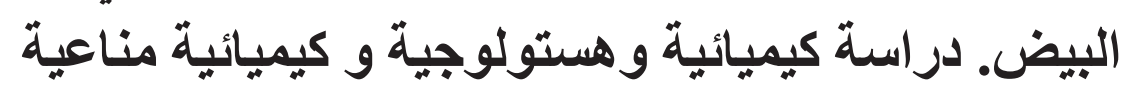

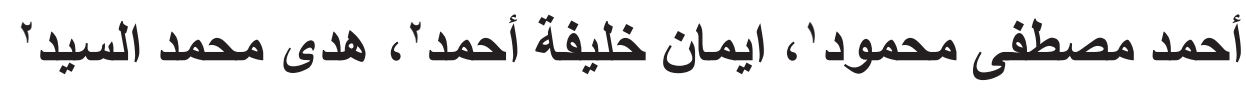

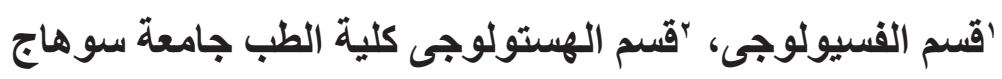

مقدمة: يعتبر العقم مشكلة صحية رئيسية تؤثر على حياة الإنسان. تساهم عو امل متعددة في عقم الذكور.,وومن أهمها هو التعرض للملوثات البيئية مثنل بيسفينول أ. الهدف من العمل: در اسة التأثير الوقائي المحتمل للأحماض الدهنية أوميغا 3 ضد التغيير ات التي يسبيها بيسفسنول أ في محور الخصية و الغدة النخامية في ذكور الجرذان. المواد وطرق الفحص: تم استخدام ثناثون من ذكور الجرذان البيضاء في الدراسة. تم تقسيمه بالتساوي إلى ثناثة

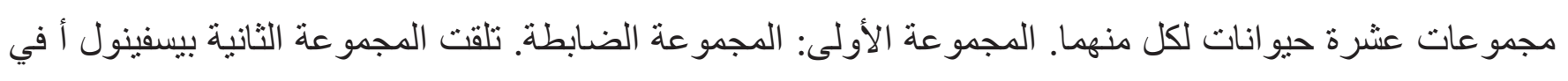
جر عة 1.2 ملغ / كغم عن طريق الفم 6 أيام في الأسبوع. تلقت المجموعة الثالثة أوميغا 3 بجرعة 0.4 مغ / كغ تحت الجلد بالإضافة إلى بيسفينول أ من نفس الجر عة و المدة السابقة. في وقت التشريح ، نم تخدير جميع الجرذان عن طريق الأثير ، وتم جمع عينات الدم لتقدير التستوستيرون ، الهرمون المصفر ، الهرمون المحفز للحويصلة والبرولاكتين. تم تشريح الخصية واختبار الغدة النخامية وتحضير ها للار اسة النسيجية و الكيمياءالنسيجية المناعية ل 3 Caspaseو ، PCNA ، لفحص التكاثر الخلوى و الموت المبرمج للخلايا ولخلايا المفرزة لهرمون البرو لاكتين. تم حساب عدد الخلايا الإيجابية وتحليلها إحصائياً. النتائج: انخفاض ملحوظ في الهرمون المصفرو التستوستيرون مع زيادة ملحوظة في البرو لاكتين في المجموعة المعاملة بييسفينول أ. ظهرت الخلايا المنوية غير منظمة ومنتكسة. كما لوحظ تجز ء و انكماش انوية خلايا spermatid. تم الكثف عن زيادة كبيرة ذات دلالة احصائية في معدل موت الخلايا المبرمج و انخفاض ملحوظ في معدل تكاثر الخلايا الجرثومية مع التعرض لبييسفينول أ مقارنة مع المجمو عة الضابطة. كثنت در اسة الغدة النخامية تغيير ات تتكسية في الخلايا حامضية الاصطباغ والخلايا قاعدية الاصطباغ في المجموعة الثانية للحيو انات مع انخفاض كثافة الصبغة المناعيةلالخلايا المفرزة لهرمون اللبن. لوحظ تحسن هذه التغييرات في المجموعة الثالثة بإعطاء الأحماض الدهنية

الاستنتاج: قد يحمي أوميجا 3 من التأثير ات الخطرة المحدثة بواسطة بيسفينول أ فى محور الغدة النخامية و الخصية. الكلمات الرئيسية: العقم ، بيسفينول أ ، أو ميغا 3 ، محور الغدة النخاميةو الخصية ، الهرمون المصفر ، التيستوسنيرون، البرو لاكتين. 